\title{
LA CONSTITUCIONALIZACIÓN DEL DERECHO FINANCIERO EN EL DERECHO COLOMBIANO*
}

\author{
CONSTITUTIONALIZATION FINANCIAL \\ LAW IN THE COLOMBIAN LAW
}

\section{A CONSTITUCIONALIZAÇÃO DO DIREITO FINANCEIRO NO DIREITO COLOMBIANO}

"Con excelentes magistrados, las malas leyes son todavía soportables"

Platón

\section{RESUMEN}

El artículo analiza la llamada Constitucionalización del Derecho Financiero en Colombia, buscando responder a la pregunta: ¿El Derecho Financiero en el régimen de Derecho Colombiano está constitucionalizado? A partir de esta inquietud se formula una correlativa: ¿Cuáles son los efectos e implicaciones de dicha Constitucionalización? Se responde que con la entrada en vigencia de la Constitución Colombiana de 1991, evidentemente el Derecho Financiero se constitucionalizó a tal grado, que además de ser considerada la actividad como de servicio público, es claro que las entidades financieras actúan en ejercicio de una autorización del Estado para cumplir uno de sus fines, el cual es el de la prestación de los servicios públicos, por lo cual gozan de algunas prerrogativas propias de

* Este artículo es producto de la investigación terminada que será sustentada por el autor como parte de su tesis doctoral en la Universidad Santo Tomás de Aquino.

a. Abogado de la Universidad Santo Tomás de Aquino. Especialista en Derecho Comercial de la Universidad Externado de Colombia. Magister en Derecho Puro Universidad Nacional de Colombia. Doctorando en Derecho Universidad Santo Tomás de Aquino. Miembro de número del Colegio de Abogados Comercialistas. Profesor Universitario Universidad Santo Tomás de Aquino, Universidad Incca de Colombia. Actualmente se desempeña como Jefe de Litigios Especiales del Banco Davivienda S. A.

William Jiménez $\mathrm{Gil}^{\mathrm{a}}$ williamjimenez@wjgestudiojuridico.com Fecha de recepción: 8 de Marzo 2014 Fecha de revisión: 31 de Marzo 2014 Fecha de aceptación: 22 de Mayo 2014
MISIÓN JURÍDICA Revista de Derecho y Ciencias Sociales Bogotá, D.C. (Colombia)

Colaboradores Externos Internacionales Núm. 7, Año 2014

enero-diciembre, pp. 145-165.

ISSN $1794-600 \mathrm{X}$ 
la actividad, pero igualmente se obligan a cumplir condiciones mínimas de derechos de los usuarios, que restringe cabalmente su ejercicio.

\section{PALABRAS CLAVES}

Constitucionalización, derecho financiero, servicio público, derechos de los consumidores, autonomía de la voluntad, viejo derecho, nuevo derecho, racionalidad, argumentación.

\section{ABSTRACT}

This article analyzes the Constitutionalization of Financial Law in Colombia, seeking to answer the question: Is the Financial Law at the Colombian regime constitutional law? This concern originates a correlative: What are the effects and implications of such Constitutionalization? The answer is that with the entry into force of the Colombian Constitution of 1991. Financial Law was evidently constitutionalized to such an extent that besides the activity being considered as public service, it is clear that financial institutions act with authorization from the State to fulfill one of its purposes, which is the provision of public services, this allows some prerogatives of the activity, but also makes them fulfill user rights to the minimum, which completely restricts its practice.

\section{KEYWORDS}

Constitutionalization, Financial, Public Service, Consumer rights, autonomy, old right, new right, rationality, argument.

\section{RESUMO}

0 artigo analisa a chamada Constitucionalização do Direito Financeiro na Colômbia, buscando responder à pergunta: Será que o Direito Financeiro no regime colombiano é direito constitucional? A partir desta preocupação é uma fórmula correspondente: Quais são os efeitos e implicações de tal Constitucionalização? A resposta é que com a entrada em vigor da Constituição colombiana de 1991, obviamente o direito financeiro foi constitucionalizado a tal ponto, que além da atividade ser considerada como serviço público, é evidente que as instituições financeiras atuam no exercício de uma autorização do Estado para atender a um dos seus objetivos, que é o de prestação de serviços públicos pelo cual gozam de algumas prerrogativas próprias da atividade, mas também são obrigadas à cumprir com as condições mínimas dos direitos dos usuários, o que restringe o seu pleno exercício.

\section{PALAVRAS-CHAVE}

Constitucionalização, direito financeiro, serviço público, direitos do consumidor, autonomia, direito velho, novo direito, racionalidade, argumentação.

\section{INTRODUCCIÓN}

En Colombia, a partir de la entrada en vigencia de la Constitución de 1991, se discute vivamente si el Derecho en general, y el Derecho Privado en particular, están o no constitucionalizados; pues hay quienes afirman que existe un exceso en la aplicación del Derecho Constitucional a todas las áreas del Derecho; casi siempre quienes afirman esto se alían en el bando de los enemigos de $l a$ constitucionalización del derecho, pues consideran que se ha desarticulado además el sistema de fuentes del Derecho, en donde la ley, que era la fuente por excelencia, resulta remplazada por la jurisprudencia de la Corte Constitucional merced a la aplicación del precedente como regla obligatoria de carácter general.

En palabras de Tamayo Jaramillo, quizá el crítico más conspicuo y puntilloso, "ya no se trata de interpretar el orden jurídico vigente, sino de estudiar los precedentes constitucionales, con su carga de subjetivismo axiológico carente de respaldo normativo".

Para Tamayo Jaramillo, la Corte Constitucional Colombiana aplica la interpretación que él denomina valorista, según la cual los textos de la ley y de la misma constitución deben ser desatendidos si ello es indispensable para lograr la realización del Estado Social de Derecho y demás valores constitucionales. En su criterio "un precedente obligatorio que desconoce el texto de la Constitución y de las leyes es supremamente peligroso porque destruye el principio de legalidad y convierte a los jueces en rango inferior en simples autómatas de la voluntad de las altas Cortes".

1 TAMAYO JARAMILLO, J. La decisión judicial. Naturaleza, hermenéutica y aplicación del Derecho, 2011 
Tamayo Jaramillo y los seguidores de lo que el mencionado autor ha denominado Positivismo discrecional, consideran que el Neoconstitucionalismo violenta manifiestamente la regla del artículo 230 de la Constitución Colombiana, el cual expresamente señala que los jueces en sus actuaciones están sometidos al imperio de la ley, que entienden como una norma única expedida por el Congreso, es decir, ley en sentido formal, y no como lo entiende la Corte Constitucional, ley en sentido material, lo que tendría unos alcances más amplios, pues no se reduciría al tenor literal de la norma escrita por el legislativo, sino que implicaría todo el contenido ideológico, o valorista, que la regla involucraría por ser de textura abierta. Para Tamayo "cuando el artículo 230 C. P. habla de sometimiento a la ley, significa que el Juez está sometido a todo tipo de normas -constitucionales, legales y administrativasque hacen parte del sistema jurídico, pero aplicando la o las normas que regulan cada caso" ${ }^{2}$ y no aplicando en su totalidad el ordenamiento jurídico, con miras a la realización de los valores máximos de la Constitución y la justicia como lo afirma la Corte, pues según Tamayo Jaramillo, entonces la seguridad de la que habla la Corte, sería una utopía.

$\begin{array}{cccc}\text { En general, los opositores } & \text { al } \\ \text { Neoconstitucionalismo } & \text { conciben que } & \text { el }\end{array}$
mismo está desbordado, arrasa con los textos normativos establecidos en los Códigos vigentes, reemplazados por valores constitucionales no positivizados, y por ende la seguridad jurídica así como el principio de legalidad y el Estado de derecho desparecen, para dar entrada a una dictadura judicial, donde las normas vigentes y aplicables no son las de los códigos, o las de la Constitución, sino la interpretación que de los valores constitucionales tenga la Corte.

Otro grupo, por el contrario, considera que el ejercicio del Derecho y, en general, la práctica de la aplicación judicial en Colombia, cambiaron con la constitución de 1991. Por ende hablan de un Nuevo Derecho, consideran que debe ser el análisis de los principios generales de derecho consagrados en ella (que hacen referencia a las nociones de vida digna, igualdad de trato frente a la ley, buen nombre, libertad de empresa y

2 TAMAYO JARAMILLO, J. El precedente judicial en Colombia. Colombia: Universidad Javeriana. Editorial Gustavo Ibañez. (2012) asociación, garantía de la propiedad privada, libre competencia, solidaridad, autonomía de la voluntad, protección del medio ambiente, debido proceso, etc., entre otros), o que por conexidad le son aplicables (caso de las nociones de vivienda digna, mínimo vital, fomento de las empresas de la economía solidaria, servicios públicos esenciales aplicados al caso de los servicios bancarios y financieros y las empresas prestadoras de servicios públicos domiciliarios y de salud, etc.), los que remplazan y le dan un caris diferente a la otrora visión egoísta, individualista y puramente liberal del concepto de Derecho privado y Derecho mercantil, que regulaban estas instituciones.

Afirman los seguidores del nuevo derecho, que un Derecho Constitu cionalizado, basado en valores y estructurado sobre principios, más que reglas, asegura un Derecho más cercano a la justicia, que concilia las realidades de un país esencialmente inequitativo, pero fundamentalmente permite un ejercicio de argumentación más racional y coherente; útil en sistemas jurídicos como el colombiano caracterizado por la inestabilidad jurídica y una constante ausencia de justicia. Para quienes defienden el nuevo derecho, tal visión frente a la adjudicación judicial, permite reconocer que la ley no opera en situaciones de igualdad real o material, sino que ha sido concebida por el legislador desde una óptica puramente teórica, que concibe a los ciudadanos como iguales, desde una visión puramente formal, pero que no se compadece con lo que en el mundo real se observa. Concluyen que la seguridad jurídica no la da el texto de la ley, sino su debida y racional interpretación y aplicación a casos prácticos.

El objeto del candente debate expuesto es a lo que se ha dado en llamar la Constitucionalización del Derecho, y cualquiera sea la posición que se tome frente al mismo, no puede ser desconocido ni negado. Menos en un campo de la actividad económica vital para cualquier sociedad, como lo es el de la actividad financiera.

\section{PROBLEMA DE INVESTIGACIÓN}

Dicho fenómeno ha irradiado la totalidad de las esferas jurídicas, y resulta particularmente interesante su efecto en el campo del Derecho Financiero, de aquí que el presente ensayo busque dar respuesta a la siguiente pregunta: ¿El Derecho Financiero en el régimen de Derecho Colombiano está constitucionalizado? A partir 
de esta inquietud se formula una correlativa: ¿Cuáles son los efectos e implicaciones de dicha Constitucionalización?

\section{METODOLOGÍA}

El presente ensayo utiliza un enfoque cualitativo, el cual se usa, primero para descubrir y refinar preguntas de investigación, y posteriormente para probar hipótesis; se basa en métodos de recolección de datos sin medición numérica, con descripciones y observaciones, esencialmente de jurisprudencia y normas legales.

\section{QUÉ ENTENDEMOS POR DERECHO FINANCIERO Y CUÁL ES SU ALCANCE FRENTE A LA CONSTITUCIONALIZACIÓN DEL DERECHO.}

Acotar el ámbito de estudio del presente ensayo resulta trascendente, y por ende para los efectos del mismo, entenderemos la actividad financiera con los alcances que le da Martínez Neira, es decir:

(...) el conjunto de principios y normas que gobiernan la formación, el funcionamiento, la actividad y la liquidación ordenada de las instituciones que tienen por objeto la captación, el manejo, el aprovechamiento y la inversión de fondos provenientes del ahorro del público, así como el ofrecimiento de servicios auxiliares de crédito. $^{3}$

En este sentido, no podemos reducir la actividad financiera exclusivamente al conjunto de operaciones activas, pasivas y neutras que realizan los bancos, sino que de una manera más amplia debemos considerar, como claramente lo expresa el profesor Martínez Neira, el conjunto de instituciones que captan, manejan, aprovechan e invierten fondos provenientes del ahorro público.

Es decir, que al analizar el tema, debemos considerar la actividad desarrollada por entidades como las compañías de seguros, las compañías de leasing, de financiamiento comercial, fiduciarias, empresas de factoraje, almacenes generales de depósito, uniones de crédito, administradoras de

3 MARTÍNEZ NEIRA, N. H. (1994). Sistemas Financieros. Santafé de Bogotá: BIBLIOTECA FELABAN. MARTINEZ NEIRA, N. H. (2004). Cátedra de derecho bancario colombiano (Segunda Edición ed.). Bogotá D. C.: Legis Editores S. A. fondos de inversión, administradoras de fondos de pensiones, administradoras de fondos de cesantías, fondos mutuos de inversión e, incluso, en un sentido amplio, deberíamos incluir a las empresas solidarias que a través de modalidades de ahorro solidario manejan recursos de sus asociados, tales como cooperativas de ahorro y crédito, cooperativas de aporte y crédito, cooperativas financieras, fondos de empleados, mutuales, y bancos solidarios, e incluso en el caso Colombiano. También se debe considerar la particular situación de entidades como las Cajas de Compensación Familiar y otro tipo de entidades similares que desarrollan dentro de su quehacer actividades financieras de las mencionadas por Martinez Neira.

Ahora bien, mirado el tema desde la óptica del estudio jurisprudencial que en el ámbito constitucional ha dado lugar a la llamada Constitucionalización del Derecho Financiero en Colombia, la realidad indica que una buena parte, por no decir que el conjunto de los fallos más trascendentes y significativos sobre el tema, emanados de la Corte Constitucional, se refieren a Bancos y Compañías de Seguros. Con todo, el principio de irradiación de la jurisprudencia constitucional, la fuerza expansiva de estas normas, determina que los precedentes fijados por la Corte sean aplicables a las demás entidades que desarrollen actividades iguales o similares a la de los bancos y compañías de seguros, sobre la base de la consideración del principio de igualdad frente a la ley. Por lo tanto frente a un mismo fundamento de hecho se deberá aplicar una misma regla jurídica, regla jurídica que, en el caso en estudio, no corresponde a una regla de carácter legal, sino a una sub regla proveniente del precedente jurisprudencial.

\section{LA NOCIÓN DE SERVICIO PÚBLICO DE LA BANCA, SENTENCIA SU-157 DE 1.999. M. P. ALEJANDRO MARTÍNEZ CABALLERO}

Son innumerables los fallos que en los últimos años ha emitido la Corte Constitucional, tanto en vía de constitucionalidad, sentencias $\mathrm{C}$, como resolviendo la protección especial de derechos fundamentales mediante acciones de tutela o amparo, Sentencias T y Sentencias SU o de unificación. Sin embargo, de todas ellas hay un grupo especial de fallos que hoy en día configuran una línea de precedente jurisprudencial muy clara, que encuentra su Sentencia hito en la 
SU-157 de 1999, a partir de la cual se entendió que la actividad financiera en general y el ejercicio de la banca en particular, son considerados como un servicio público. Es más, la Corte reconoce que el tratamiento de servicio público de la actividad financiera que prestan los bancos, no es una consideración nueva, sino que en vigencia de la Constitución de 1886 se reconocía a partir del año 1959. Veamos:

El 22 de octubre de 1.995, el presidente de los Estados Unidos de América, Bill Clinton, expidió la Orden Ejecutiva 12978 titulada "Blocking Assets and Prohibiting Transactiones with Significant Narcotics Traffickers", la cual se dirige a congelar activos y prohibir transacciones con importantes traficantes de narcóticos. El documento señaló varios nombres de personas presuntamente vinculadas con los llamados "carteles" del narcotráfico y dispuso que, en ese país, sean sancionadas todas las personas que celebren negocios con las personas que figuren en la mencionada lista. El 21 de diciembre de 1.995 la Embajada de Estados Unidos de América en Colombia, informó al Gobierno nacional, a la Asociación Bancaria y a las Entidades Financieras de Colombia, que los banqueros colombianos "no deben prestar servicio bancario a los «Narcotrafincantes Específicamente Señalados»(...) los banqueros que presten tal servicio corren el riesgo de ser incluidos en la lista de «Narcotrafincantes Específicamente Señalados», y con ello no podrán hacer ningún negocio con el sistema de los Estados Unidos". El listado y la información general sobre los «Narcotraficantes Específicamente Señalados», fueron dados a conocer a los medios de prensa nacionales quienes publicaron los hechos. Dos ciudadanos colombianos que figuraban en la lista "Blocking Assets and Prohibiting Transactiones with Significant Narcotics Traffickers", más conocida como "Lista Clinton", solicitaron y obtuvieron de la Dirección Nacional de Fiscalías y del Departamento Administrativo Nacional de Seguridad DAS, certificación de que contra los ciudadanos en cuestión no cursaba investigación alguna por violación a la Ley 30 de 1.986, ni registraban antecedentes judiciales o de policía según el Art. 12 del Código de Procedimiento Penal. Varias entidades financieras colombianas, entre otros BANCO DAVIVIENDA

4 Corte Constitucional, Sentencia SU-157 de 1.999. M. P. Alejandro Martínez Caballero
S. A., COOPDESARROLLO, BANCO DE BOGOTÁ, CORPORACIÓN AHORRAMAS S. A., BANCO INDUSTRIAL COLOMBIANO S. A.; saldaron unilateralmente cuentas de ahorro, cuentas corrientes, depósitos en CDTs y otras operaciones financieras que mantenían con las dos personas objeto de la tutela base de la Sentencia analizada. Los peticionarios en razón de los hechos atrás enumerados y considerando que han sido objeto de un "bloqueo financiero", demandaron se les ampararan sus derechos fundamentales al buen nombre, igualdad y al debido proceso.

Los jueces de instancia, de Cali y Bogotá, respectivamente, negaron los amparos solicitados argumentando que no existía trasgresión de derecho fundamental alguno. Que se trataba de controversias contractuales que deberían ventilarse ante la jurisdicción ordinaria. Que la acción de tutela no está prevista como un medio procesal que pueda operar frente a particulares, en este caso entidades del sector financiero, ya que lo que se discutía es una controversia de origen legal que debe resolverse en la justicia civil, a más de que las entidades financieras gozan de autonomía contractual que autoriza la terminación unilateral de los contratos bancarios, tal y como lo establece el Art. 1389 del Código de Comercio. Uno de los jueces de instancia, además, argumento que ningún tribunal nacional es competente para cuestionar la inclusión de una persona en un documento extranjero, pues aquello rebasa la jurisdicción colombiana.

Cabe aquí destacar los términos en que se estructura el debate jurídico, pues la controversia se plantea sobre la óptica de si el problema a resolver es exclusivamente de derecho privado, lo que llevaría a resolverlo por la vía de una interpretación legalista, preponderando la autonomía de la voluntad, y aplicando a tabla rasa la regla legal del artículo 1389 del Código de Comercio (viejo derecho); o si el tema trasciende el ámbito del derecho privado y toca con el tema de derechos fundamentales, caso en el cual la autonomía de la voluntad queda relegada para privilegiar la aplicación de principios constitucionales de grado superior, buen nombre, derecho a la intimidad, debido proceso, derecho a la igualdad frente a la ley y el principio de solidaridad, todos ellos de rango constitucional (nuevo derecho). Como se observa, los jueces de instancia privilegiaron el derecho privado por encima del derecho constitucional. 
La Corte Constitucional estudió el tema en instancia de revisión, e inició el análisis del caso, considerando el punto relativo a la jurisdicción que tienen los jueces colombianos para conocer de una acción de tutela, que se fundamenta en la posible trasgresión de derechos fundamentales en Colombia, por la acción de algunas entidades financieras y la omisión de autoridades Colombianas. Encontró que dicha jurisdicción es plena, pues precisamente la razón de ser de la tutela es remediar la trasgresión de derechos fundamentales en Colombia.

Encontró la Corte que la base sobre la que se fundamenta la eventual trasgresión de los derechos fundamentales, propuesta por los peticionarios, tiene que ver con la inclusión de estos en un listado o documento realizado fuera del territorio Colombiano y por autoridades extranjeras, razón por la cual la intervención de las autoridades judiciales sólo está llamada a analizar las consecuencias jurídicas internas de la cancelación sucesiva de cuentas bancarias a personas que consideran transgredidos sus derechos fundamentales en Colombia y el consecuente efecto constitucional para las entidades financieras accionadas, lo cual de acuerdo con los artículos $4^{\circ}$ y 241 de la Carta es un deber imperativo de la Corte Constitucional.

Consideró la Corte que el asunto en estudio tiene que ver con la terminación unilateral de contratos bancarios de los peticionarios, y que este hecho se origina en la inclusión de sus nombres en un documento de gobierno extranjero destinado a combatir el delito de narcotráfico, lo cual implica una sanción, sin debido proceso, que les anula sus libertades económicas, les afecta el buen nombre y su derecho a la intimidad. Además, la actitud asumida por las entidades financieras contra quienes se promueve la tutela, impide que en el futuro los peticionarios puedan acceder al crédito en el sistema financiero colombiano.

La Corte encontró que la acción de tutela era procedente por cuanto, de acuerdo con lo preceptuado en el artículo 86 de la Constitución y el artículo 42 del Decreto 2591 de 1991, la acción de tutela contra particulares sólo procede en cuatro casos taxativamente señalados, a saber:

- Cuando aquellos prestan un servicio público,
- cuando su conducta afecta grave y directamente el interés público,

- cuando el solicitante se encuentre en estado de subordinación y

- finalmente cuando se presente la indefensió respecto del accionado.

Para la Corte Constitucional, pese a que no existe norma que de manera expresa así lo determine, en el derecho Colombiano es claro que la actividad bancaria es un servicio público, pues sus nítidas características así lo determinan. La jurisprudencia de la Corte Constitucional ha reconocido el carácter de servicio público de la industria bancaria. Al respecto se dijo:

(...) la actividad relacionada con el manejo, aprovechamiento e inversión de los recursos captados al público, atendiendo a su propia naturaleza, reviste interés general y, por tanto, no escapa al postulado constitucional que declara su prevalencia sobre intereses particulares (artículo 1ํ de la Constitución Política), lo cual se concreta en el carácter de servicio público"(negrillas y cursivas fuera de texto). ${ }^{5}$

La Corte Constitucional ha dejado en claro que si un particular asume la prestación de la actividad bancaria adquiere una posición de supremacía material -con relevancia jurídicafrente al usuario; es decir, recibe unas atribuciones especiales que rompen el plano de igualdad referido, y que, por ende, en algunos casos, sus acciones $u$ omisiones pueden vulnerar un derecho constitucional fundamental que requiere de la inmediata protección judicial.

Por consiguiente, las personas jurídicas que desarrollan la actividad bancaria, independientemente de su naturaleza pública, privada o mixta, actúan en ejercicio de una autorización del Estado para cumplir uno de sus fines, que es el de la prestación de los servicios públicos, por lo cual gozan de algunas prerrogativas propias de la actividad, pero igualmente se obligan a cumplir condiciones mínimas de derechos de los usuarios. En consecuencia, la acción de tutela en contra de quienes prestan un servicio público es formalmente procedente.

5 Sentencia T-426 de 1992. M. P. Eduardo Cifuentes Muñoz 
Encuentra la Corte que el punto central del debate tiene que ver con la autonomía de la voluntad privada en el sector bancario. Los bancos y Corporaciones de Ahorro y Vivienda demandados, fundamentan su decisión en el artículo 1389 del Código de Comercio, en donde expresamente se faculta a las partes de los contratos bancarios para terminar unilateralmente los vínculos, en cualquier término. Así las cosas, podría pensarse que la controversia se sitúa en un plano meramente legal, pues surge de una relación contractual que debe resolverse en la justicia civil. Sin embargo, la función especial y la cualificación de los prestadores del servicio público de la actividad bancaria exigen el análisis de la incidencia constitucional de la autonomía privada, que se manifiesta en la libertad contractual de los bancos, y derechos constitucionales de los usuarios del servicio, tales como la personalidad jurídica, la igualdad, las libertades económicas y el derecho al buen nombre.

Entiende la Corte que la autonomía privada dentro de una Estado Social de Derecho, como es el nuestro, presenta limitaciones y cortapisas que no pueden ser pasadas por alto por los particulares al momento de manifestar su voluntad, obligarse y desarrollar los negocios jurídicos propios de la libertad de empresa y la discrecionalidad que caracteriza el ámbito de lo privado.

Con la introducción de la cláusula social del Estado de Derecho, se exige que las actividades económicas particulares se desarrollen dentro del marco de la función social. Así pues, es claro que la autonomía negocial "se inscribe en la dinámica de la libertad que reconoce a toda persona el poder de decidir su propia esfera personal y patrimonial", 6 dentro del marco del bien común, el principio de solidaridad y los derechos de los demás. Por lo tanto, se concibe la libre actuación privada allí donde se le reconoce al individuo el derecho, no sólo a tener una conducta activa y basada en la propia iniciativa, sino a reaccionar como homo economicus a determinadas dinámicas del mercado.

Las libertades propias de la autonomía privada están sometidas a condiciones y límites que le son impuestos, también constitucionalmente, por las exigencias propias del Estado social, el

6 Sentencia C-134 de 1.994. M. P. Eduardo Cifuentes Muñoz interés público y por el respeto de los derechos fundamentales de otras personas (C.P. art. $1^{\mathrm{o}} \mathrm{y}$ 95-1). Esto significa que la Constitución, como norma fundamental (artículo 4ํㅗ superior), señala las directrices para todo el ordenamiento jurídico, por lo que la legislación de derecho privado también debe ser interpretada y aplicada a la luz de la Constitución y con ella de los derechos fundamentales. De esta forma, los derechos fundamentales vinculan a los poderes públicos y a los particulares, pues la Carta fundamental tiene también una eficacia horizontal. Es por ello que los poderes públicos deben intervenir en la esfera negocial para asegurar un orden económico y social justo, con el objetivo promover la prosperidad general y garantizar la efectividad de los derechos y deberes que la Constitución consagra (C.P. art. $2^{\circ}$ ).

La Corte entiende que la función bancaria no es igual a la actividad que realiza cualquier particular en el ejercicio de la autonomía privada. Esto se explica con el análisis de los preceptos constitucionales que claramente limitan el radio de acción de la libertad contractual para las entidades financieras, como el artículo 335 de la Constitución, el cual establece que la prestación del servicio bancario, como parte integrante de la actividad financiera, es de interés público, lo que significa que esta actividad debe buscar el bienestar general.

La definición de interés público aún no parece unívoca, puesto que aquel puede considerarse como un concepto jurídicamente indeterminado. Por lo tanto, la Corte considera que, en la actividad bancaria, esta noción se materializa en estas premisas:

- El acceso a la prestación del servicio público bancario es restringido, como quiera que la propia Carta establece como requisito previo e indispensable para el desarrollo de esa labor la autorización del Estado.

- El concepto de interés público de la actividad bancaria se concreta en la garantía de un trato igual de los usuarios para el acceso al servicio, puesto que si bien aquella debe asegurar la solvencia de quien participa en el sistema, la no aceptación de los clientes sólo debe responder a factores objetivos y razonables que impliquen un riesgo económico para la entidad financiera, como quiera que se impone la universalidad del ahorro. 
- En relación con la igualdad entre los usuarios para acceder a los servicios públicos, la Corte Constitucional ha sido clara en manifestar que el concepto genérico de igualdad incluye el de homogeneidad de oportunidades, para alcanzar la eficiente prestación de aquellos. La sentencia SU-560 de 1997 M. P. José Gregorio Hernández, que estudió el tema de la igualdad de acceso y permanencia en el servicio público de educación, dijo:

Si bien la Constitución protege la actividad económica, la iniciativa privada y la libre competencia (art. 333 C.P.) y reconoce también el derecho de los particulares de fundar centros educativos (art. 68 C.P.), tales libertades no pueden anular ni disminuir el carácter de servicio público y de función social atribuido por la Constitución Política a la educación, que también y sobre todo es un derecho fundamental, por todo lo cual está sujeta a la suprema inspección y vigilancia del Estado (art. 67 C.P.), siendo de competencia del legislador la función de fijar las condiciones para la creación, gestión y funcionamiento de los aludidos establecimientos. ${ }^{7}$

- De lo expuesto se concluye que la autonomía de la voluntad negocial de las entidades financieras, en muchos aspectos, está más restringida que la del resto de particulares, pues se encuentra especialmente limitada en razón de la función que desempeñan, a la especialidad de la actividad que prestan y a su condición de instrumento para garantizar derechos individuales, como quiera que la libertad negocial también se limita por la prohibición de afectar desproporcionadamente derechos fundamentales y por el impedimento del abuso del derecho propio.

En el campo de las relaciones jurídicas que se traban entre los particulares, tiene especial relevancia el artículo 14 de la Constitución, el cual consagra el derecho al reconocimiento de la personalidad jurídica como una verdadera garantía de la persona natural para que goce de la capacidad jurídica o de la aptitud para ser titular de derechos y obligaciones, no sólo de contenido extra patrimonial sino también

$7 \quad$ Colombia, Corte Constitucional, SU-560, 6 de noviembre de 1997, Magistrado Ponente José Gregorio Hernández, Gaceta de la Corte Constitucional, Bogotá, 1982. de carácter económico, lo que implica una integración potencial a la vida negocial y al tráfico jurídico de una sociedad. Por tanto, al individuo le debe ser posible participar en la vida social y económica no sólo a la hora de concretar sino de configurar algunos aspectos básicos del régimen económico. Con fundamento en lo dicho, la Corte define la siguiente sub-regla: no puede haber personas a quienes se les niegue la personalidad jurídica, ya que ello equivaldría a privarles de la capacidad de ejercer derechos y contraer obligaciones. Si esto es así, surge un corolario, las entidades financieras no pueden arbitrariamente y de manera subjetiva negar el acceso a servicios financieros a una persona, pues esto implicaría tácitamente negarle su personalidad jurídica.

Como consecuencia de lo anterior, se encuentra prohibida la sanción que elimine indefinidamente la posibilidad de acceder a las actividades económicas lícitas, dentro de ellas, el ingreso a la actividad bancaria.

Con todo, podría argumentarse, que corresponde al Legislativo la determinación sobre cuándo la autonomía privada queda sujeta a restricciones, derivadas de la protección de derechos constitucionales; por lo que al juez no le correspondería la aplicación directa de los derechos constitucionales en las relaciones privadas. La Corte manifiesta que esa tesis es parcialmente acertada, pues es indudable que, entre particulares, la doble función de los derechos fundamentales es nítida. De un lado, rechazan la intervención injustificada del poder estatal, por lo que buscan la defensa de sus aspectos esenciales. De otro, representan un deber de protección que obliga a la intervención del Estado cuando se quebranta la igualdad y se evidencian desigualdades fácticas inmensas, por lo que los derechos fundamentales también se constituyen en barreras frente al poder de los particulares.

En este contexto, si bien las libertades económicas no son derechos fundamentales per se y que, además, pueden ser limitados ampliamente por el Legislador, no es posible restringirlos arbitrariamente ni es factible impedir el ejercicio, en igualdad de condiciones, de todas las personas que se encuentren en condiciones fácticamente similares (C.P. art. 13 y 333). 
Por consiguiente, es viable predicar la ius fundamentalidad de estos derechos cuando se encuentren en conexidad con un derecho fundamental, esto es, cuando su ejercicio sea el instrumento para hacer efectivo un derecho fundamental. Por lo tanto, concluye la Corte, "es claro que el derecho a la iniciativa privada de los accionantes se encuentra directa $e$ inescindiblemente ligado con dos derechos fundamentales: el reconocimiento a la personalidad jurídica y el de la igualdad".

En este orden de ideas, no podría sostenerse la tesis que patrocine la absoluta imposibilidad, legal o práctica, de acceder a la actividad financiera, pues la total discrecionalidad de las entidades financieras implicaría negar el carácter de interés público de la actividad bancaria, los derechos de los clientes a la personalidad jurídica y a ejercer, en condiciones de igualdad, la libre iniciativa privada.

De aquí, que la Corte concluya que, evidentemente, la actitud de las entidades financieras demandadas, al terminar unilateralmente las relaciones contractuales con los peticionarios, rebasa el limite racional y justo que la autonomía de la voluntad concede y, por ende, con tal comportamiento se violan los derechos fundamentales a la personalidad jurídica $\mathrm{y}$ a la igualdad, derechos que son tutelados.

Sin embargo, el amparo otorgado por la Corte no puede extenderse a obligar a las entidades financieras a restablecer los contratos unilateralmente terminados, esto por cuanto, a juicio de la Corte, la libertad de contratación que involucra el derecho a acceder y a mantenerse en el sistema financiero, está supeditado a que la actuación de los particulares no violente el núcleo esencial del derecho.

\section{EL NÚCLEO ESENCIAL DEL DERECHO EN EL EJERCICIO DE LA ACTIVIDAD FINANCIERA}

El núcleo esencial de un derecho

(...) es aquella parte de su contenido que es absolutamente necesaria para que los intereses jurídicamente protegibles, que dan vida al derecho, resulten real, concreta y efectivamente protegidos. De este modo, se rebasa o se desconoce el contenido esencial cuando el derecho queda sometido a limitaciones que lo hacen impracticable, lo dificultan más allá de lo razonable o lo despojan de la necesaria protección". ${ }^{9}$

Por consiguiente, el respeto del núcleo de los derechos se impone a las autoridades y a los particulares.

En este sentido la Corte en Sentencia T-443 de 1992. M. P. José Gregorio Hernández Galindo puntualizó:

La actividad relacionada con el manejo, aprovechamiento e inversión de los recursos captados al público, atendiendo a su propia naturaleza, reviste interés general y, por tanto, no escapa al postulado constitucional que declara su prevalencia sobre intereses particulares, lo cual se concreta en el carácter de servicio público que se le atribuyó desde 1959 y que, tanto a la luz de la Constitución anterior como de la actual -en este último caso mientras la ley no defina el concepto de servicios públicos esenciales- faculta al Ejecutivo para impedir la huelga en dicha actividad y para convocar tribunales de arbitramento obligatorios. Si el Congreso de la República, al ejercer la función que le confía el artículo 36 de la Carta, elabora una definición que clasifique a la actividad bancaria y financiera por fuera del concepto 'servicio público esencial', el derecho de huelga podría ser ejercido por los trabajadores a ella vinculados dentro de las normas que el propio legislador establezca" (negrillas fuera de texto). ${ }^{10}$

En ese mismo sentido se pronunció la Corte en Sentencia C-122 de 1999. M. P. Fabio Morón Díaz.

La actividad bancaria, dada su caracterización y trascendencia dentro del marco de organización jurídico-política propia del Estado Social de Derecho, es un servicio público, pues además de la importancia de la labor que desempeñan los establecimientos del sector financiero, públicos y privados, la misma está ligada directamente al interés de la comunidad, que reclama las condiciones de permanencia, continuidad y regularidad que le son inherentes, y su regulación

9 Colombia. Corte Constitucional, Sentencia T-426 de 1992. M. P. Eduardo Cifuentes Muñoz

10 Colombia. Corte Constitucional, Sentencia T-443, 6 de julio de 1992, M. P. José Gregorio Hernández Galindo Colombia, Bogotá, 1992. 
y control son responsabilidad directa del Estado. A partir de los anteriores presupuestos, se entiende por qué, el Constituyente, en el caso específico de los establecimientos de crédito, le impuso al Estado el deber de regular su actividad, condicionándola y sometiéndola a unas reglas y controles específicos, que deben operar de manera tal que se realice el principio superior que señala la primacía del interés general sobre el particular; ese deber de regulación incluye, desde luego, el deber de hacer efectiva la responsabilidad de los agentes económicos proveedores de bienes y servicios, específicamente de los propietarios y administradores de los establecimientos de crédito" (negrillas y subrayado fuera de texto). ${ }^{11}$

En el caso en estudio, entiende la Corte, que el comportamiento de las entidades financieras al terminar los contratos existentes con los peticionarios, fue sustentada en criterios objetivos, racionales y que no implicaban abuso de la libertad negocial privada. La banca Colombiana considera que la "lista Clinton" si es una causal objetiva que aprueba su decisión, como quiera que el riesgo bancario derivado de la relación comercial con los peticionarios es muy alto, puesto que Estados Unidos sanciona a los Norteamericanos que negocian con quienes figuran en la lista. Por ende, si la entidad bancaria colombiana desea mantener relaciones comerciales con personas de esa nacionalidad, no debe ofrecer sus servicios a los presuntos "traficantes de narcóticos".

La Corte resalta que, en efecto, la mayoría de las entidades financieras Colombianas mantienen relaciones comerciales muy importantes con la banca Norteamericana, por lo que las medidas adoptadas en nuestro país se dirigen a proteger a las instituciones financieras colombianas de riesgos inminentes, propiciados por la fuerte capacidad de intimidación que tiene la banca norteamericana sobre el mercado financiero colombiano. En consecuencia, los efectos "reflejo" de la "lista Clinton" producen un estado de indefensión indudable para la banca colombiana, por lo que se considera que ella debe defender el interés general de los ahorradores.

Así las cosas, tal y como se plantean en la actualidad los hechos, la negociación con

11 Colombia. Corte Constitucional, Sentencia C-122, 1 de marzo de 1999, M. P. Fabio Morón Díaz, Bogotá, 1999. quienes aparecen en la "lista Clinton", pero en general en cualquier reporte relativo no solamente a narcotráfico, caso de los eventos SARLAFT $^{12}$, sino igualmente a lavado de activos o movimiento de recursos financieros que hayan tenido un origen ilícito o que tengan que ver con actividades de terrorismo, podría propiciar un desequilibrio económico desproporcionado para el sistema financiero colombiano, el cual debe ser minimizado en aras de proteger el ahorro del público.

Concluye la Corte que, si bien el derecho a la personalidad jurídica y el derecho a la igualdad de los pretensores se encuentra conculcado, la reparación de estos derechos fundamentales no le corresponde al sector financiero, sino que se traslada a las autoridades colombianas.

La Sentencia SU-157 de 1.999, sienta de manera perentoria las condiciones para ponderar el derecho a la libertad de empresa y la autonomía de la voluntad de los particulares, indicando que dichas actividades tienen una doble faceta, como generadores de derechos pero igualmente de obligaciones; recalca la Corte la función social que en un Estado Social de Derecho tiene la iniciativa privada. Igualmente reitera la naturaleza de servicio público que tiene la actividad financiera en Colombia, estableciendo el contenido obligacional que acompaña a quienes ejercen dicha actividad. Sin embargo, al momento de analizar el núcleo esencial de derecho a la personalidad jurídica de los pretensores, enfrentado a la autonomía negocial de los demandados, sector financiero, encuentra la Corte que hay razones objetivas racionales, basadas en el interés general que priman sobre la necesidad de protección y amparo de los derechos de los peticionarios. De aquí que considere que la determinación puramente contractual de las

12 En desarrollo de lo señalado en los artículos 102 y siguientes del Estatuto Orgánico del Sistema Financiero, en consonancia con el artículo 22 de la Ley 964 de 2005 y demás normas complementarias, la Superintendencia Financiera de Colombia expidió la Circular Externa 022 de 2007, que establece los criterios y parámetros mínimos que las entidades vigiladas deben atender en el diseño, implementación y funcionamiento del Sistema de Administración del Riesgo de Lavado de Activos y de la Financiación del Terrorismo (SARLAFT). Dicha circular obliga no solamente al reporte de eventos que estén configurados dentro de los riesgos mencionados, que corresponden especialmente al reputacional, legal, operativo y contagio; sino fundamentalmente la terminación de los contratos que se tengan con clientes que sean personas o entidades que estén involucradas con las actividades de lavado de activos y/o financiación del terrorismo. 
entidades financieras no fue abusiva, y por tanto considere que se ajusta al marco constitucional.

\section{LA ACTIVIDAD BURSÁTIL TIENE TAMBIÉN LA CONNOTACIÓN DE SERVICIO PUBLICO, SEGÚN LA SENTENCIA SU 166-99}

Ahora bien, al igual que sucede con las entidades financieras, especialmente bancos y compañías de seguros, la actividad bursátil es de interés público (C.P. art. 335). Vale la pena aclarar que la función bursátil se relaciona con la compraventa de valores, por lo cual se incluyen los comisionistas de bolsa. Así pues, el carácter de interés público de esa actividad se concreta en la inspección y vigilancia que, otrora, ejercía la Superintendencia de Valores, quien debía intervenir para mantener el mercado bursátil debidamente organizado, velar para que quienes participen en él desarrollen su actividad en condiciones de igualdad, transparencia y que no se ponga en peligro ni se lesione el interés público, específicamente el interés de los inversores.

Así mismo, el ejercicio de la actividad bursátil está limitado sólo para quienes ostentan la autorización gubernamental, así, por ejemplo, para ser comisionista de bolsa se requiere cumplir con condiciones especiales como ser una sociedad anónima y un objeto social exclusivo y determinado, eso es: desarrollo del contrato de comisión para la compra y venta de valores y el cumplimiento de requisitos personales y económicos, previamente definidos por la ley o la reglamentación al respecto (Ley 45 de 1990, Decreto 1172 de 1980 y Resoluciones 400 y 1200 de 1995 de la Superintendencia de Valores). De igual manera, el ejercicio de la actividad es reglado, como quiera que la legislación y la inspección gubernamental determinan cuáles transacciones deben llevarse a cabo obligatoriamente a través de bolsas de valores, qué montos y cómo deberá efectuarse cada transacción.

En este orden de ideas, la Corte Constitucional en Sentencia SU166-99, determinó que:

La autonomía negocial de los comisionistas de bolsa se encuentra limitada no sólo por la ley sino por la Constitución, pues esta última norma también se proyecta a las relaciones entre particulares. Sin embargo, ello no quiere decir que todas las relaciones comerciales de quienes desempeñan una actividad de interés público adquieren rango constitucional, pues ello vaciaría el contenido de la normatividad ordinaria y desconocería la esencia de la norma rectora del ordenamiento jurídico. No obstante, en ocasiones, la autonomía particular de quienes desempeñan esas actividades podría involucrar derechos constitucionales. ${ }^{13}$

El caso resuelto por la Corte tiene que ver con un accionante que poseía 49.000 acciones preferenciales, sin derecho a voto, del Banco Ganadero, representadas en el título valor número 15578866. En razón a que el monto de las acciones excede de \$500.000, cualquier negociación debe realizarse por medio de la bolsa de valores. El accionante argumenta que necesitaba vender sus acciones, por tal razón, acudió al comisionista de bolsa ASVALORES S.A, quien se negó a negociar con el accionante, por cuanto se encuentra en la publicitada orden ejecutiva del Presidente de Norteamérica, la denominada "Lista Clinton" atrás mencionada. El actor considera que la empresa comisionista de bolsa ASVALORES S.A le vulneró el principio a la dignidad humana y los derechos a la igualdad, petición, buen nombre y debido proceso. En consecuencia, solicita que "se autorice y perfeccione la negociación de las 49.000 acciones preferenciales que sin derecho de voto tengo en el Banco Ganadero representadas en el Título 15578866".14

Los jueces de instancia que conocieron de la tutela consideraron que el contrato de comisión para la compra y venta de valores se fundamenta en la autonomía de la voluntad privada de los comisionistas, como quiera que no existe disposición legal que obligue a aceptar los encargos solicitados por los inversionistas. Por lo tanto, concluyen que "no puede ni debe este Juez jurisdiccional de tutela meterse o inmiscuirse en un negocio de tráfico jurídico netamente civil, regulado por leyes preestablecidas para casos concretos".15

De acuerdo con el artículo 1ำ del Decreto 1172 de 1980 "son comisionistas de bolsa quienes estando inscritos en el Registro Nacional de Intermediarios han sido aceptados por una Bolsa de Valores". A su turno, el artículo 7ํ de la Ley 45 de 1990 dispone que "las sociedades comisionistas de bolsa deberán

13 Colombia. Corte Constitucional, SU 166, 17 de marzo de 1999, M.P. Alejandro Martínez Caballero, Bogotá, 1999.

14 Ibid.

15 Ibid. 
constituirse como sociedades anónimas y tendrán como objeto exclusivo el desarrollo del contrato de comisión para la compra y venta de valores". Por lo tanto, el comisionista de bolsa es quien se dedica profesionalmente a ejercer el contrato comercial de comisión, esto es, a desarrollar una "especie de mandato" para la ejecución de uno o varios negocios, en nombre propio, pero por cuenta ajena (artículo 1287 del Código de Comercio). Así pues, el contrato mercantil de comisión se fundamenta en el acuerdo de voluntades, pues sólo se concreta si el comisionista acepta expresa o tácitamente la gestión encomendada. Por ello, la autonomía privada para negociar es de la esencia del contrato, como quiera que se reconoce a las partes la libertad, la capacidad para decidir y el plano de igualdad en el que se encuentran.

Afirma la Corte que la autonomía privada para negociar no es absoluta ni que su ejercicio es siempre del mismo grado, pues el ordenamiento jurídico y la propia Constitución distinguen campos en donde la autonomía privada está regulada por normas imperativas o irrenunciables, esto es, normas que se aplican en cualquier caso y, por lo tanto, se imponen a la voluntad de los particulares. Ejemplos tradicionales, como la contratación laboral y los acuerdos para prestar servicios públicos, así como paradigmas contemporáneos como el respeto por los derechos fundamentales y las normas superiores, permiten aclarar la aplicación de la autonomía privada en el derecho civil actual.

Concluye la Corte que al igual que sucede con las entidades financieras, la actividad bursátil es de interés público (C.P. art. 335). Vale la pena aclarar que la función bursátil se relaciona con la compraventa de valores, por lo cual se incluyen los comisionistas de bolsa. En este sentido la autonomía negocial de los comisionistas de bolsa está ampliamente limitada y sometida a un control estatal estricto y directo. En efecto, el Estado ha intervenido en esta actividad de manera especial para prevenir conductas delictivas, tales como, el lavado de activos y la utilización de esta labor para fines diferentes al interés público. Dentro del abanico de normas relativas a controlar y prevenir el blanqueo de activos en la actividad bursátil, se encuentran:

- Los artículos 39 y 40 de la Ley 190 de 1995, establecieron controles a las personas sometidas a la inspección, vigilancia y control de la Superin- tendencia de Valores.

- El artículo 103 del Estatuto Orgánico del Sistema Financiero, dispone que las sociedades comisionistas de bolsa deberán dejar constancia, en formulario especialmente diseñado al efecto, de la información relativa a las transacciones en efectivo que realicen, cuyo valor sea superior a la suma de $\$ 7,500.000$,oo.

- Varias circulares, entre las cuales se encuentran la Circular externa 014 de 1995 y 003 de 1997, expedidas por la Superintendencia de Valores, en las que se fijan los mecanismos y procedimientos para la prevención del lavado de activos a través del mercado público de valores.

- La Ley 27 de 1990 determinó la necesidad de que los comisionistas de Bolsa implementen mecanismos para el conocimiento del cliente y a las Bolsas de Valores les señaló la obligación de reportar a la Fiscalía General de la Nación las operación que se estimen sospechosas, el deber de controlar las transacciones en efectivo y la adopción de una serie de procedimientos por parte de quienes participen en el mercado público de valores, por cuyo desconocimiento habría lugar a la imposición de las sanciones pertinentes.

- Acuerdo de cooperación mutua entre el gobierno de Colombia y el gobierno de los Estados Unidos de América, para combatir, prevenir y controlar el lavado de dinero proveniente de actividades ilícitas, suscrito en San Antonio, Texas el 27 de febrero de 1992.

Con base en lo expuesto, la Corte Constitucional se pregunta: ¿la decisión del comisionista de bolsa accionado transgrede los derechos fundamentales al reconocimiento de la personalidad jurídica e igualdad de acceso a la actividad bursátil del peticionario? El fallo contenido en la Sentencia SU-166-99 responde "que sólo es factible la protección de los derechos en comento, si se transgrede el núcleo esencial de los mismos o si existe un bloqueo económico." Para ello, la Sala señaló estas condiciones:

b1. Cuando al cliente le es imposible actuar de manera efectiva para neutralizar los efectos de las decisiones de los bancos. Por lo tanto, no constituye una situación de bloqueo financiero si existen medios administrativos o jurídicos que le permitan acceder al sistema financiero... 
b2. También se presenta el bloqueo financiero cuando el usuario está frente a la imposibilidad de ingreso al servicio público bancario. Por consiguiente, transgreden desproporcionadamente los derechos del cliente, las decisiones en cadena o reiteradas indefinidamente que impiden hacer uso de la banca...

b3. Cuando la decisión de las entidades financieras produce consecuencias graves para la capacidad jurídica del usuario del servicio público...

b4. Cuando la negativa de negociación no responde a causas objetivas y razonables que justifican la decisión... (negrillas fuera de texto). ${ }^{16}$

En la medida en que en el caso sub judice no se dieron ninguna de las circunstancias señaladas, concluye la corte que no es dable tutelar el derecho.

\section{LA ACTIVIDAD ASEGURADORA Y LOS DERECHOS FUNDAMENTALES. EL CASO DE LA SENTENCIA T-1165 DE 2001}

La actividad aseguradora ha sido objeto de varios pronunciamientos de la Corte Constitucional, en los cuales ha determinado importantes modulaciones a la interpretación de normas del Código de Comercio que regulan el contrato de seguro. Entre las sentencias más relevantes, encontramos la T-1165 de 2001. El problema principal que se suscita en este fallo, es la no expedición de la póliza de vida grupo deudores por parte de la Aseguradora Solidaria, a los accionantes, por tratarse de portadores del virus VIH. En virtud de lo anterior, los actores interponen acción de tutela contra la aseguradora Solidaria, solicitando la protección de su derecho a la vida, la intimidad, la igualdad y por conexidad el derecho a una vivienda digna (Art. 51 de la Constitución Política). En desarrollo de esta acción, manifiestan que fueron honestos en declarar su condición de ser portadores asintomáticos del VIH, en la declaración de asegurabilidad, y que fue ésta la razón por la cual la aseguradora no aceptó su inclusión en la póliza de vida grupo deudores, cuyo tomador es el Megabanco.

Por su parte, la aseguradora Solidaria manifestó la libertad que le asistía para asumir un riesgo y que, para el caso en mención, la

16 Sentencia SU-166-99, Op. Cit. compañía no podía admitir en el grupo asegurado a los accionantes en referencia, en tanto que eran portadores del VIH, riesgo que no estaba dentro de sus políticas de cobertura.

El Juez de tutela de primera instancia concedió el amparo pues consideró que la posición asumida por la compañía aseguradora es discriminatoria, rompe el principio de igualdad frente a la ley, pero adicionalmente desconoce el principio de solidaridad que debe ser considerado de manera especial en los casos de enfermos del VIH. El juez constitucional de segunda instancia revoco el amparo otorgado pues consideró que adicional a que el derecho a la vivienda digna invocado por el accionante no es un derecho fundamental susceptible de tutela, la entidad demandada es una entidad de naturaleza privada que con su decisión no pretende vulnerar ningún derecho, simplemente no quiere contratar con determinadas personas, hecho que no significa que los demandantes se encuentran inhabilitados para acceder al seguro de vida, ya que cuentan con la posibilidad de acudir a otra aseguradora con el fin de obtener la póliza reclamada, pues se advierte en su escrito de tutela que los actores sólo solicitaron el seguro de vida a una entidad, sin acudir a otra empresa aseguradora en procura de obtener la póliza reclamada.

La Corte Constitucional analiza el caso y encuentra que si bien la acción se formula contra un particular, regido por el Derecho Privado, contra quien, en principio, sería improcedente la acción de tutela, en los términos del artículo 86 de la Constitución y 42 del decreto 2591 de 1991, para el caso en estudio se acepta su procedencia. Lo anterior dado el estado de indefensión en que se encuentran los actores, quienes al ser portadores asintomáticos del virus de inmunodeficiencia humana, ven frustrados sus derechos, por el abuso de poder que en cierta medida ejerce la aseguradora, al decidir de manera arbitraria negar la suscripción de la póliza de vida.

Adicionalmente, y lo que es prioritario para el presente ensayo, la Corte Constitucional ha señalado que:

(...) de acuerdo con el artículo 335 de la CP., $\mathbf{l a}$ actividad aseguradora es de interés público y se ejerce con arreglo a la ley. Consulta el interés público que en los contratos de seguros, 
la parte débil que, por lo general, se identifica con el asegurado o beneficiario, realizadas las condiciones a las que se supedita su derecho reciba efectivamente y en el menor tiempo posible la prestación prometida. El mérito ejecutivo que se atribuye a las pólizas en los casos examinados, neutraliza y frustra las prácticas abusivas a las que podrían recurrir las empresas aseguradoras. Estas últimas, de ordinario, no sólo despliegan su poder en el momento inicial, al fijar unilateralmente las condiciones generales del contrato, sino que en el curso de la relación negocial - se ha observado por parte del legislador histórico, de manera no infrecuente, esquivan o dilatan injustificadamente el cumplimiento de sus compromisos. La disposición legal citada es el medio al cual ha recurrido la ley para introducir un factor de equilibrio entre asegurado o beneficiado y el asegurador" (negrillas fuera de texto). ${ }^{17}$

Respecto al Derecho a la Vivienda Digna, considera la Corte que

(...) a pesar de estar contemplado en nuestra Constitución dentro del capítulo de los denominados derechos económicos sociales y culturales, puede ser considerado como un derecho de rango fundamental en relación con el derecho a la vida en condiciones dignas; pero para que esto sea posible es necesario analizar con especial detenimiento las circunstancias que rodean el caso concreto, pues sólo así se podrá determinar si la necesidad de vivienda, lleva consigo elementos que involucran la dignidad, o la vida de quien acude a esta instancia judicial. ${ }^{18}$

El derecho a la vivienda digna en abstracto no hace parte de los derechos fundamentales, pero en algunas circunstancias lo sería si está en conexidad con otros derechos fundamentales. En este sentido ha puntualizado al Corte:

El Juez de Tutela debe acudir a la interpretación sistemática, finalista o axiológica para desentrañar, del caso particular, si se trata o no de un derecho fundamental, lo que podría denominarse una "especial labor de búsqueda", científica y razonada por parte del Juez.

17 Corte Constitucional. Sentencia T-1165 de 2001, M.P. Alfredo Beltrán Sierra

18 Ibid.
El Juez está frente a lo que la doctrina denomina un "concepto jurídico indeterminado": los derechos constitucionales fundamentales, que pueden ser o no ser al mismo tiempo o ser simultáneamente de una manera o de otra, pero siempre su sentido se define bajo las circunstancia de tiempo, modo y lugar. (...) La labor que realiza el Juez de Tutela es de verificación; él no crea el derecho fundamental, lo desentraña y verifica. Esta "teoría de la verificación" también es desarrollada por Dworkin sobre la figura del Juez modelo, capaz de encontrar racionalmente la solución justa. "El Juez no tiene una función creadora, sino garantizadora de los derechos"(negrilla fuera de texto).

(...) el derecho a una vivienda digna no otorga a la persona un derecho subjetivo a exigir del Estado, de manera directa, una prestación determinada. Los derechos constitucionales de desarrollo progresivo o derechos programáticos, condicionan su efectividad a la previa obtención de las condiciones materiales que los hacen posibles.

Por esto es acertado afirmar que, en principio, los derechos de segunda generación no son susceptibles de protección inmediata por vía de tutela. Situación diferente se plantea una vez las condiciones jurídico-materiales se encuentran de manera que la persona ha entrado a gozar de un derecho de esta categoría. En dado caso, el derecho constitucional materializado adquiere fuerza normativa directa y a su contenido esencial deberá extenderse la necesaria protección constitucional. ${ }^{19}$

Entiende la Corte que, en el caso concreto objeto de análisis, los accionantes tienen derecho a que se les ampare el Derecho a una Vivienda Digna, pues para acceder al crédito que les permitirá adquirir la propiedad del inmueble en el que aspiran a vivir, resulta indispensable obtener un seguro que cubra la vida de los deudores hipotecarios, de forma tal que la obtención del seguro se vuelve un medio para la consecución del fin primordial que es la obtención de la vivienda, lo cual les garantiza una vida digna.

Ahora bien, el tema de si la autonomía de la voluntad y la libertad de contratación admiten que la aseguradora niegue a los accionantes el seguro solicitado, es un tema que no puede ser mirado en abstracto. Así las cosas, si bien existe una disposición legal contemplada en el

19 Ibid. 
Estatuto Orgánico del Sistema Financiero, artículo 100, que protege la libertad de tomadores y asegurados para decidir la contratación de los seguros y escoger sin limitación la aseguradora de su preferencia, la Corte no deja de advertir que, en este caso, los demandantes optaron por la Aseguradora Solidaria de Colombia, pues fue esa aseguradora la que en principio estuvo dispuesta a contratar con ellos, expidiendo a su favor la póliza que protege el inmueble en caso de incendio y de terremoto, no así la póliza de vida, bajo la excusa de que son portadores de VIH.

Para la Corte, esta conducta asumida por la entidad aseguradora, es discriminatoria y no consulta los propósitos que rigen el Estado Social de Derecho, fundado en el respeto a la dignidad humana, pues no se puede concebir, bajo ningún argumento, que el ser portador asintomático de VIH sea una exclusión para adquirir un seguro de vida. No hay ninguna disposición legal que así lo contemple $\mathrm{y}$, de existir, dicha disposición desconocería los postulados constitucionales.

Las normas contenidas en el Código del Comercio, señalan que toda persona tiene interés asegurable en su propia vida, en la de las personas a quienes puedan legalmente reclamar alimentos y en la de aquellas cuya muerte o incapacidad pueden aparejarle un perjuicio económico, aunque este no sea susceptible de evaluación cierta (artículo 1137 del Código de Comercio). Igualmente, para tomar un seguro de vida, no es necesario realizar un examen médico, pues únicamente se exige que el tomador declare sinceramente los hechos o circunstancias que determinen el estado de riesgo (artículo 1158 ibidem).

En el caso de la suscripción de una póliza de vida, se parte de un supuesto y es que cualquier póliza que se suscriba, se encuentra sometida a un hecho cierto e indeterminado, cual es la muerte del tomador o asegurado, razón por la que aunque existan niveles probables de vida, no se puede tener la certeza de cuándo se producirá el deceso del tomador del seguro. Por tanto, no es jurídicamente admisible que se niegue la suscripción de la póliza de vida a una persona asintomática de virus de inmunodeficiencia humana, bajo el argumento que dicha persona va a morir más rápido que otra que no tenga esa condición; ello resulta discriminatorio y en consecuencia violatorio de la Constitución
Política (artículo 13). Es claro, entonces, que no hay ninguna razón que justifique la decisión, por pate de la aseguradora demandada, de no expedir el seguro de vida solicitado por los demandantes. Si bien la Aseguradora Solidaria de Colombia, se encuentra amparada por la autonomía de su voluntad en las relaciones contractuales, esta autonomía, no puede constituirse en un abuso de su posición en detrimento de los derechos de quien acude a ella. De aceptar, la Corte, que la aseguradora acusada puede dejar de suscribir un seguro de vida, bajo el argumento de que la persona que lo solicita padece del virus de inmunodeficiencia humana, sería como aceptar toda forma de discriminación, desconociendo los preceptos constitucionales y las normas contenidas en el derecho internacional. Por ello decide la Corte amparar los derechos tutelados y, en consecuencia, ordenarle a la aseguradora que un término de 48 horas siguientes al fallo emita en condiciones de igualdad la póliza de seguro de vida solicitado por los accionantes.

Es importante recalcar en este caso, cómo la Corte Constitucional presupone que, en los casos de Contratos de Seguro, las condiciones predispuestas del contrato, por ser un contrato formulario, generan una posición dominante en cabeza de la aseguradora, la cual rompe el equilibrio prestacional del contrato y facilita la posibilidad de cláusulas abusivas, que ameritan que el Juez constitucional, en aras de lograr una igualdad efectiva frente a la ley, garantice ese derecho interpretando el alcance y límites del acuerdo de voluntades suscrito entre las partes. El principio de igualdad no impone la obligación constitucional de establecer un trato igual a todos los sujetos de derecho, o destinatarios de las normas, de una manera matemática e irrestricta, sino que reconoce la existencia de situaciones disímiles, frente a las cuales el legislador puede, válidamente, establecer consecuencias jurídicas diferentes, dentro del ejercicio de su competencia. La jurisprudencia constitucional ha dejado en claro que el principio de igualdad, así entendido, exige un trato idéntico para supuestos iguales o análogos y permite una regulación distinta frente a circunstancias que presentan características diferentes, pues pretende establecer la identidad entre los iguales y la diferencia entre los desiguales. Puede existir un trato diferente siempre y cuando sea razonable y justo; si la diferenciación no es razonable o es injusta, se convierte en una forma de discriminación, 
efectivamente proscrita por la Constitución $\mathrm{Al}$ respecto, es claro que las discriminaciones que se establecen frente a hipótesis análogas, o iguales, quiebran el principio constitucional a la igualdad, cuando carecen de justificación.

\section{La Corte ha reconocido así mismo, que}

(...) el trato diferente para fenómenos también diversos tiene que fundarse igualmente en motivos razonables que justifiquen la diferencia, con el objeto de no eliminar de plano la igualdad, por una apreciación exagerada de características distintas. En otras palabras las divergencias de trato para fenómenos desiguales tienen que ser proporcionales a la desigualdad misma sobre la cual recaen..$^{20}$

\section{CONCLUSIONES}

Expuestos estos casos, que han sido escogidos por ser paradigmáticos, pero que no reducen el amplio espectro factico sobre el cual ha tenido oportunidad la Corte Constitucional de pronunciarse, pues aquí cabría mencionar otros fallos no menos importantes (así por ejemplo toda la línea jurisprudencial relativa al tema de los créditos hipotecarios en UPAC, las sentencias que han hecho mención a la obligación de los Bancos de suspender el cobro de obligaciones crediticias en los casos de deudores secuestrados y/o desplazados, la Sentencia C-364 de 2.000 sobre el principio de igualdad en relación con la regla sobre pago de intereses legales moratorios civiles e intereses legales moratorios comerciales, entre otros), se demuestra, muy claramente, que el tema del Derecho Financiero ha sido profusamente estudiado por la Corte Constitucional.

En este orden de ideas, la primera pregunta planteada relativa a si ¿El Derecho Financiero en el régimen de Derecho Colombiano está constitucionalizado?, debe ser respondida con una contundente respuesta afirmativa, sustentada en el sinnúmero de fallos que a lo largo de este escrito se han relacionado.

Un aspecto más complejo de contestar tiene que ver con la siguiente inquietud relativa a establecer ¿Cuáles son los efectos e implicaciones de dicha Constitucionalización? En este sentido podemos concluir lo siguiente:

- La Corte Constitucional ha dejado establecido de manera clara y precisa que la actividad desarrollada por los bancos y las compañías de seguros, pero por esa misma vía, y sobre la base de la fuerza expansiva de los derechos fundamentales, las demás actividades financieras que realizan otras entidades del sector, tienen el carácter de servicio público.

- La naturaleza de servicio público de la actividad financiera, se predica en razón de que el manejo, aprovechamiento e inversión de los recursos captados al público, reviste interés general, pues tiene que ver con el ahorro del público.

- Igualmente, la Corte recalca que la actividad financiera lleva implícita el hecho de que la entidad prestadora del servicio adquiere una posición de supremacía material -con relevancia jurídica- frente al usuario; es decir, recibe unas atribuciones especiales que rompen el plano de igualdad referido, y, por ende, en algunos casos, sus acciones u omisiones pueden vulnerar un derecho constitucional fundamental que requiere de la inmediata protección judicial.

- Las entidades financieras actúan en ejercicio de una autorización del Estado para cumplir uno de sus fines, el cual es la prestación de los servicios públicos, por lo cual gozan de algunas prerrogativas propias de la actividad, pero igualmente se obligan a cumplir condiciones mínimas de derechos de los usuarios.

- La Corte considera que la noción de interés público que reviste la actividad financiera, por ser un servicio público, se materializa en estas premisas:

- El acceso a la prestación del servicio público financiero es restringido, como quiera que la propia Carta establece como requisito previo e indispensable para el desarrollo de esa labor la autorización del Estado.

- El concepto de interés público de la actividad financiera se concreta en la garantía de un trato igual de los usuarios para el acceso al servicio, puesto que, si bien aquella debe asegurar la solvencia de quien participa en el sistema, la no aceptación de los clientes sólo debe responder a factores objetivos y razonables que impliquen 
un riesgo económico para la entidad financiera, como quiera que se impone la universalidad del ahorro.

- En relación con la igualdad entre los usuarios para acceder a los servicios públicos, la Corte Constitucional ha sido clara en manifestar que el concepto genérico de igualdad incluye el de homogeneidad de oportunidades para alcanzar la eficiente prestación de aquellos.

- Entiende la Corte que la autonomía privada dentro de una Estado Social de Derecho, como es el nuestro, presenta limitaciones y cortapisas que no pueden ser pasadas por alto por los particulares al momento de manifestar su voluntad, obligarse y desarrollar los negocios jurídicos propios de la libertad de empresa y la discrecionalidad que caracteriza el ámbito de lo privado.

- Las limitaciones que se imponen a la autonomía de la voluntad en el ejercicio de negocios jurídicos propios de la actividad financiera, generan como consecuencia, la prevalencia de los principios constitucionales consagrados en la Carta, los que priman sobre las reglas jurídicas de corte positivo previstas en los Códigos. De aquí que, frente a conflictos de índole interpretativa sobre la aplicación de una regla legal, enfrentada a un principio de rango constitucional, prevalecerá el principio constitucional.

- A partir de la entrada en vigencia de la Constitución de 1991, todos los actores privados, quienes nos movemos dentro del mercado, debemos estar plenamente conscientes de que la esfera función social nos impone nuevas y serias obligaciones que van más allá de las propias del contrato.

- Que estamos sometidos a un régimen superior basado en la solidaridad, la equidad, la buena fe, la igualdad, pero esencialmente el respeto al derecho de los otros, un régimen que pretende ser moralmente justo y ajustado para permitir el ideal de una convivencia en donde todos quepamos y todos seamos actores principales.

- Se diferencia la problemática del abuso de posición dominante en el mercado, que es un problema puramente legal de Derecho privado, con la problemática del abuso del derecho, la restricción al ejercicio de la libertad de empresa, y la protección de derechos fundamentales, que nos ubica en la tesis de la protección horizontal de los derechos fundamentales, sin perder de vista que normas de rango legal deberán propugnar por la eficaz promoción de la competencia.

Finalmente, la tensión entre derechos fundamentales y autonomía de la voluntad, en defensa de la libertad negocial, es un tópico que aún se mueve en la jurisprudencia de la Corte Constitucional en términos claros-oscuros, líneas grises que indican el temor de la Corte por afrontar de manera expedita y sin ambages la defensa de la libertad y la igualdad por encima de la defensa del mercado. Se observan casos en los cuales la Corte ha reconocido que las actitudes de los particulares demandados son violatorias de derechos fundamentales, sin embargo tímidamente, quizá con celo excesivo en defensa de intereses colectivos o generales y la primacía de las leyes del mercado, ha ponderado la libertad negocial enfrentada al derecho fundamental, y sobre la tesis del núcleo esencial de los derechos fundamentales en juego, ha estimado que no se dan las condiciones para tutelar los derechos. Menciono a título de ejemplo los casos relativos a personalidad jurídica vs. libertad contractual en relación con entidades del sector financiero; salud pública vs. libertad contractual en los casos de contratos de medicina prepagada; buena fe vs. libertad contractual en los casos de preexistencias y determinación de excluyentes de responsabilidad en contratos de seguros.

Hay sin embargo un peligro latente, y es el hecho de que con la mejor de las intenciones resultemos en el peor de los mundos, pues magistrados probos $\mathrm{y}$ honestos garantizan en un sistema principialista, decisiones razonables, coherentes y justas. Pero con esta misma herramienta, magistrados abyectos $\mathrm{y}$ deshonestos, tienen el camino abierto para con hábil ejercicio retorico construir fallos políticos, sesgados, parcializados, que más que impartir justicia repartan dadivas a los áulicos de turno. 


\section{BIBLIOGRAFÍA}

- ACARELLI, T. (1962). Iniciación al estudio del derecho Mercantil. Barcelona, Cataluña, España: Casa Editorial Bosh.

- AGUILO REGLA, J. (2003). De nuevo sobre "independencia e imparcialidad de los jueces y argumentación jurídica”. Jueces para la Democracia.

- ALEXY, R. (1997). Teoría de los derechos fundamentales. Madrid, Madrid, España: Centro de Estudios Constitucionales.

- ARANGO RIVADENEIRA, R. (1994, Julio). El valor de los principios fundamentales en la interpretación constitucional. Revista de derecho Público (5).

- ATIENZA RODRÍGUEZ, M. (2006). El derecho como argumentación. Madrid, Madrid, España: Editorial Ariel.

- ATIENZA RODRÍGUEZ, M. (2007). Las piezas del Derecho (4a. Edición ed.). Barcelona, Cataluña, España: Editorial Ariel S. A.

- ATIENZA, Manuel y RUÍZ MANERO, Juan. (1996). Las Piezas del Derecho. Teoría de los enunciados jurídicos. Barcelona, España: Editorial Ariel S. A.

- BERNAL PULIDO, C. (2005). El Derecho de los derechos (1a. Edición ed.). (U. E. Colombia, Ed.) Bogotá D. C., Colombia.

- BERNAL PULIDO, C. (2009). El Neoconstitucionalismo y la Normatividad del Derecho. Bogotá D. C., Colombia: Universidad Externado de Colombia.

- BOTERO MARINO, C. y. (2007). El conflicto de las altas Cortes colombianas en torno a la tutela contra sentencias, en Estado de derecho y sentencias judiciales. Bogotá D. C., Colombia: instituto Latinoamericano de Servicios Legales Alternativos.

- BOURDIEU, P. (1998, Marzo). La esencia del neoliberalismo. Le mode diplomatique.

- BOURDIEU, P. (2010). La miseria del mundo (Cuarta reimpresión ed.). (F. d. económica, Ed., \& H. Pons, Trans.) México D. F., México: Fondo de Cultura Económica.
- CALDERÓN VILLEGAS, J. J. (2011). La constitucionalización del Derecho Privado (1a Edición ed.). (E. Temis, Ed.) Bogotá D. C., Colombia: Universidad del Rosario. Universidad de Los andes.

- CARBONELL, M. y. (2007). La globalización y el orden jurídico (1a. Edición ed.). Bogotá D. C., Cundinamarca, Colombia: Universidad Externado de Colombia.

- CELEMÍn CAICEDO, J. A. (2001, Mayo). ¿Por qué es necesario el concepto de eficacia horizontal para una máxima proteccón de los derechos fundamentales? (L. E. A., Ed.) Revista Tutela (17), 955.

- CEPEDAESPINOSA,M.J.(1992).Introducción a la Constitución de 1991. Hacia un nuevo constitucionalismo. Bogotá D. C., Colombia: Presidencia de la República. Consejería para el Desarrollo de la Constitución.

- CEPEDA ESPINOSA, M. J. (1993). Los Derechos fundamentales en la Constitución de 1991. Bogotá D. C., Colombia: Editorial Temis S. A.

- DE SOUSA SANTOS, B. (2012). http:www. y o tube.com / wa tch ?v=lkc2 te 8 - Puc. Retrieved abril 2, 2012, from www.yotube. com.

- DE VEGA GARCIA, P. (1999). La crisis de los derechos fundamentales en el estado social. Madrid, España: Centro de estudios Constitucionales.

- DWORKIN, R. (1984). Los Derechos en serio. Barcelona: Ariel Editores S. A.

- DWORKIN, R. (1992). El imperio de la justicia (Segunda Edición ed.). (C. Ferrari, Trans.) Barcelona, España: Editorial Gedisa S. A.

- DWORKIN, R. (2007). La justicia con toga. Madrid, España: Marcial Pons.

- ELY, J. H. (1997). Democracia y desconfianza. Bogotá D. C., Cundinamarca, Colombia: Siglo del hombre Editores. 
- GARRIGUES, J. (1971). Hacia un nuevo Derecho Mercantil. Madrid, Madrid, España: Editorial Tecnos.

- GIRALDO ÁNGEL, J. (n.d.). El choque de trenes. Sobre los sistemas de interpretación jurídica en Colombia. (E. d. Andes, Producer) Retrieved Noviembre 11, 2011, from http:www.tribunales.colpsic.org.co/ documentos/Giraldo_CDT.pdf.

- GIRALDO LÓPEZ, Alejandro. CAICEDO ESPINEL, CarlosGermán. MADRIÑÁN RIVERA, Ramón Eduardo. (2012). Comentarios al Nuevo Estatuto del Consumidor. Bogotá D. C.: Legis Editores S. A.

- HART, H. L. (1965). El concepto de Derecho. (G. Carrió, Trans.) Buenos Aires, Buenos Aires, Argentina: Abeledo-Perrot.

- HART, H. L. (1978). Independencia entre derecho y moral. (R. Dworkin, Ed.) México D. F., México: Fondo de Cultura Económica.

- JIMENEZ GIL,W. (2012). Los establecimientos de comerciales y su régimen legal en Colombia: hacia una nueva concepción del régimen de establecimientos de comercio en la legislación colombiana. Bogotá D. C., Cundinamarca, Colombia: Universidad La Gran Colombia.

- JIMENEZ GIL, W. (2013, 08 8). La fuerza expansiva de los Derechos Fundamentales en las relaciones de Derecho Privado. Retrieved from WEB DOCENTE UNIVERSIDAD NACIONAL DE COLOMBIA : http://www. docentes.unal.edu.co/wjimenezg/docs/ LA $\% 20$ FUERZA $\% 20$ EXPANSIVA $\% 20$ $\% 20$ D E \% 20 LOS \% 20 DERECH OS \% 20 FUNDAMENTALES.pdf

- JULIO ESTRADA, A. (2000). La eficacia de los derechos fundamentales entre particulares (1a. Edición ed.). Bogotá D. C., Cundinamarca, Colombia: Universidad Externado de Colombia.

- KELSEN, H. (1974). Teoría Pura del Derecho. (E. U. Aires, Ed., \& M. Nilve, Trans.) Buenos Aires, Argentina: Universidad de Buenos Aires.
- KELSEN, H. (1992). Introduction to the Problems of Legal Theory. (P. \&. Paulson, Trans.) Oxford, United Kingdon: Oxford University Press.

- KENNEDY, D. (2005). Una alternativa de la izquierda fenomenológica a la teoría de la interpretación jurídica de hart /Kelsen. (UNAM, Ed., \& I. F. Sánchez, Trans.) Mexico D. F., México, México: Unam, instituto de investigaciones jurídicas.

- LÓPEZ MEDINA, D. E. (2000). El derecho de los jueces (1a. Edición ed.). (U. d. Andes, Ed.) Bogotá D. C., Colombia: Legis Editores S. A.

- LÓPEZ MEDINA, D. E. (2008). La letra y el espíritu de la ley. Bogotá D. C., Bogotá, Colombia: Universidad de los Andes Editorial Temis S. A.

- MADRIÑÁN, R. (1989). Derecho Comercial. Bogotá D. C., Cundinamarca, Colombia: Editorial Temis.

- MARTÍNEZ NEIRA, N. H. (1994). Sistemas Financieros. Santafé de Bogotá: BIBLIOTECA FELABAN.

- MARTÍNEZ NEIRA, N. H. (2004). Cátedra de derecho bancario colombiano (Segunda Edición ed.). Bogotá D. C.: Legis Editores S. A.

- MARTÍNEZ, M. (2009). La constitucionalización de la Justicia y la Autonomía judicial. Bogotá D. C., Colombia: Universidad Nacional de Colombia.

- MONTOYA VARGAS, J. (1992). La empresa en la Nueva Constitución. Revista de Derecho Privado (10), 184.

- NARVÁEZ GARCÍA, J. I. (1984). Introducción al Derecho Mercantil. Bogotá D. C., Cundinamarca, Colombia: Editorial Jurídicas Wilches.

- PINZÓN, G. (1985). Introducción al Derecho Comercial. Bogotá D. C., Cundinamarca, Colombia: Editorial Temis.

- RADBRUCH, G. (1959). Filosofía del Derecho (4a. Edición ed.). Madrid, Madrid, España: Editorial Revista de derecho privado. 
- RADBRUCH, G. (1980). Arbitrariedad legal y derecho supralegal. (A. d. Campo, Trans.) Buenos Aires, Buenos Aires, Argentina: Editorial Depalma.

- RADBRUCH, G. (1997). Introducción a la filosofía del Derecho. México D. F., México: Fondo de Cultura Económica.

- RAVASSA MORENO, G. (2001). Derecho Comercial. Bienes mercantiles. Bogotá D. C., Cundinamarca, Colombia: Ediciones Gustavo Ibañez.

- RAWLS, J. (2006). Teoría de la justicia. México D. F.: Fondo de Cultura Económica.

- REYES VILLAMIZAR, F. (2001, noviembre). Homenaje Póstumo. Ámbito Jurídico, Año IV(93), p. 13.

- RIPERT, G. (1946). La regla moral en las obligaciones civiles. (L. G. Colombia, Ed., \& C. V. Estrada, Trans.) Bogotá, Colombia: La Gran Colombia.

- RIPERT, G. (1954). Tratado Elemental de Derecho Comercial (Vol. I). Buenos Aires, Buenos Aires, Argentina: Tipografía Editora Argentina.

- RODRÍGUEZ GARAVITO, C. (2009). La globalización del Estado de derecho. (1a. Edición ed.). (CIJUS, Ed.) Bogotá D. C., Cundinamarca, Colombia: Universidad de los Andes.

- SÁCHICA, L. C. (1976). Exposición y glosa del Constitucionalismo Moderno. (E. Temis, Ed.) Bogotá D. C., Colombia.

- SÁCHICA, L. C.(2006). Derecho Constitucional Geenral (4a. Edición ed.). Bogotá D. C., Colombia: Editorial Temis.

- SARAZA JIMENO, R. (1991, Marzo 14). La crisis del derecho privado y el paso al nuevo derecho privado. El derecho del consumo. Jueces para la Democracia, 36-49.

- TAMAYO JARAMILLO, J. (2011). La decisión judicial. Naturaleza, hermenéutica y aplicación del Derecho. Bogotá D. C., Colombia: Biblioteca Jurídica Dike.
- TAMAYO JARAMILLO, J. y. (2012). El precedente judicial en Colombia. Colombia: Universidad Javeriana. Editorial Gustavo Ibañez.

- VELÁSQUEZ RESTREPO, C. A. (1996). Instituciones de Derecho Mercantil. Medellín, Antioquia, Colombia: Biblioteca Jurídica Dike S. A.

- VELÁSQUEZ RODRÍGUEZ, O. D. (2002). Nuevo Manual de Derecho Comercial. Medellín, Antioquia, Colombia: Librería Jurídica Sánchez R. Ltda.

\section{SENTENCIAS Y PROVIDENCIAS CITADAS:}

\section{Corte Constitucional}

- Sentencia C-587 de 1992 M. P. Ciro Angarita Barón.

- Sentencia C-134 de 1.994. M. P. Eduardo Cifuentes Muñoz.

- Sentencia C-083 de 1995 M. P. Carlos Gaviria Díaz.

- Sentencia C-122 de 1999 M. P. Fabio Morón Díaz.

- Sentencia C-383 de 1999. M.P. Alfredo Beltrán Sierra

- Sentencia C-700 de 1999. M.P. José Gregorio Hernández Galindo

- Sentencia C-747 de 1.999. M.P. Alfredo Beltrán Sierra

- Sentencia C-364 de 2.000. M.P. Alejandro Martínez Caballero

- Sentencias C-955 de 2000. M.P. José Gregorio Hernández Galindo

- Sentencia C-1140 de 2000. M.P. José Gregorio Hernández Galindo

- Sentencia T-426 de 1992. M. P. Eduardo Cifuentes Muñoz.

- Sentencia T-443 de 1992. M. P. José Gregorio Hernández Galindo.

- Sentencia T-240 de 1993 M. P. Eduardo Cifuentes Muñoz. 
- Sentencia T-308 de 1993 M.P. Eduardo • Sentencia T-448 de 2010. M. P. Humberto Cifuentes Muñoz.

- Sentencia T-057 de 1995. M.P. Eduardo Antonio Sierra Porto

\section{Cifuentes Muñoz.}

- Sentencia T-219 de 2001 M. P. Fabio Morón Díaz,

- Sentencia T-1165 de 2001 M. P. Alfredo Beltrán Sierra.

- Sentencia T-578 de 2001. M.P. Rodrigo Escobar Gil

- Sentencia T-587 de 2003. M. P. Marco Gerardo Monroy Cabra.

- Sentencia T-312 de 2010. M. P. Jorge Ignacio Pretelt Chaljub
- Sentencia T-726 de 2010. M. P. Juan Carlos Henao Pérez

- Sentencia T-386 del 2012. M. P. Jorge Iván Palacio Palacio

- Sentencia SU-157 de 1999. M. P. Alejandro Martínez Caballero.

- Consejo de Estado

- Sentencia del 21 de mayo de 1.999 del H. Consejo de Estado

- Gaceta Constitucional 82 de mayo 25 de 1991. Página 14. Ponencia constituyente Diego Uribe Vargas. 